\title{
François de La Mothe Le Vayer, Dialogues faits à l'imitation des Anciens
}

\section{Laura Rescia}

\section{(2) OpenEdition}

1 Journals

\section{Edizione digitale}

URL: http://journals.openedition.org/studifrancesi/9933

DOI: 10.4000/studifrancesi.9933

ISSN: 2421-5856

\section{Editore}

Rosenberg \& Sellier

\section{Edizione cartacea}

Data di pubblicazione: 1 août 2017

Paginazione: 353-354

ISSN: 0039-2944

\section{Notizia bibliografica digitale}

Laura Rescia, "François de La Mothe Le Vayer, Dialogues faits à l'imitation des Anciens», Studi Francesi

[Online], 182 (LXI | II) | 2017, online dal 01 août 2017, consultato il 07 janvier 2021. URL: http:// journals.openedition.org/studifrancesi/9933 ; DOI: https://doi.org/10.4000/studifrancesi.9933

Questo documento è stato generato automaticamente il 7 janvier 2021.

\section{(c) $(1) \&$}

Studi Francesi è distribuita con Licenza Creative Commons Attribuzione - Non commerciale - Non opere derivate 4.0 Internazionale. 


\title{
François de La Mothe Le Vayer, Dialogues faits à l'imitation des Anciens
}

\author{
Laura Rescia
}

\section{NOTIZIA}

FRANÇOIS DE LA MOTHE LE VAYER, Dialogues faits à l'imitation des Anciens, édition critique par Bruno Roche, Paris, Champion, 2015, 666 pp.

1 Tornato all'attenzione della critica soltanto con il rinnovamento delle ricerche sul libertinaggio, La Mothe Le Vayer si rivela, con la riscoperta dei suoi scritti filosofici, personaggio di grande interesse nella costellazione libertina. I dieci dialoghi qui riproposti in edizione critica, con ortografia modernizzata, permettono di misurare come egli utilizzi la strategia citazionale, andando ben oltre il semplice sfoggio di erudizione: l'adozione del burlesco, del sottinteso, dell'ironia e della distanziazione, gli consentono di elaborare una scrittura ludica e riflessiva al contempo, particolarmente adatta ad accogliere il pensiero libertino.

Un'introduzione all'edizione ricostruisce la biografia dell'autore, e contestualizza i dialoghi nel loro orizzonte storico e filosofico. L'edizione propone il ricchissimo apparato citazionale del testo nelle traduzioni dal latino e dal greco, tratte della «Collection Budé» o a cura dell'editore scientifico. Nella modernizzazione ortografica, si è deciso di conservare la punteggiatura e l'uso delle maiuscole. Il volume è corredato dalla riproduzione dell'articolo dedicato a Le Mothe Le Vayer nel dizionario di Pierre Bayle del 1740, da una buona bibliografia e da un utile indice dei nomi dei personaggi storici, mitologici e letterari. 